\title{
Retrospective evaluation of patients admitted to Karadeniz Technical University Pediatric Dentistry clinic due to trauma
}

\begin{abstract}
Purpose
Traumatic dental injuries are among the commonly observed problems in the primary and permanent teeth. The rate of prevalence of dental trauma varies globally. In this study, we investigated the type of dental trauma, related factors, and treatment procedures in children.
\end{abstract}

\section{Subjects and Methods}

During a 5-year period (January 2011-January 2016), 416 children aged in the range of 1-15 years were admitted to our clinic with dental trauma. The cause and type of the dental trauma in the primary and permanent teeth and their relation with gender and age were evaluated using the chi-square test, and their distribution by age was evaluated using regression analysis.

\section{Results}

Overall, girls and boys comprised $37 \%$ and $63 \%$ of the study population, respectively. The mean age was 8.5 years. Falls $(61.1 \%)$ were the most common cause of traumatic dental injuries, and enamel-dentin fracture (26\%) was the most common dental trauma type.

\section{Conclusions}

Traumatic dental injuries in children are common. A large proportion of patients without any clinical symptoms (15.8\%) did not seek any treatment after the trauma. Teachers, parents, and children should be informed about the action to be taken when dental trauma occurs and about the importance of immediately taking the child to a dentist after the trauma to ensure an accurate diagnosis, an optimal treatment plan, and positive outcome.

Keywords: Dental injuries; retrospective studies; pediatric dentistry

\section{Introduction}

Following dental caries, dental traumas in children cause the most significant damage to the teeth. Traumatic dental injuries frequently occur in children, and those in young adults constitute $5 \%$ of all injuries that require treatment $(1,2)$. The literature has shown that 3\%-80\% of emergency dental treatments are because of tooth injuries and the incidence of dental trauma within 1 year is $0.4 \%$ in every age group and $1.3 \%-4 \%$ in schoolage children. It has been reported that $25 \%$ of all school-age children have had a dental injury, and 33\% of adults, mostly at the age of 19 years, have experienced trauma in their permanent teeth (3).

A majority of the dental trauma cases occur during childhood bicycle accidents or sports events or as a result of a fall. Additionally, collisions, traffic accidents, home accidents, and child abuse also cause dental traumas. Traumatic injuries, such as luxation, cause dental traumas of the permanent teeth in $15 \%-61 \%$ cases and of the primary teeth in $62 \%-73 \%$ cases. Trauma types are classified into five groups based on the

\author{
Ayça Kurt' ${ }^{1}$, \\ Ömer Faruk Güdük2 (1), \\ Şengül Merve Erbek ${ }^{2}$ (D), \\ Özgül Baygın² $\mathbb{D}^{\text {, }}$ \\ Tamer Tüzüner ${ }^{2}$ (D)
}

ORCID IDs of the authors: A.K. 0000-0003-4762-7495; Ö.F.G. 0000-0003-0930-4935; S..M.E. 0000-0002-2160-4343; Ö.B. 0000-0003-0836-7619; T.T. 0000-0001-5817-5928

'Recep Tayyip Erdoğan University, Faculty of Dentistry, Deparment of Pedodontics, Rize, Turkey

${ }^{2}$ Department of Pedodontics, Karadeniz Technical University Faculty of Dentistry, Trabzon, Turkey

Corresponding Author: Ayça Kurt

E-mail:kurtayca23@gmail.com

Received: 26 January 2018 Revised: 07 May 2018 Accepted: 04 September 2018

DOI: 10.26650/eor.20195236 
treatment and healing: concussion, subluxation, extrusion, lateral luxation, and intrusion (4). Luxation injuries are the most common traumatic injuries in the primary teeth, whereas crown fractures are more frequently reported in the permanent teeth. Besides, the central incisors of the upper jaw are the most affected teeth by traumatic dental injuries in both the primary and permanent teeth (5-7).

The results obtained from studies have varied depending upon the countries and regions where the studies were conducted and the age groups of the children included in the studies. Apart from the functional, phonetic, and aesthetic disorders, psychological problems emerge in children and their families after the children frequently experienced dental injuries. Traumatic dental injuries are challenging for all physicians. Therefore, an accurate diagnosis, treatment plan, and follow-up are critical for ensuring a positive treatment outcome. The etiology of trauma, its distribution, and its consequences must be known for taking protective measures against dental traumas, preventing physical and psychological problems that may occur, and deciding upon an effective and appropriate treatment (8-11). Studies investigating the frequency of dental traumas with the causes and consequences in Turkey are needed $(12,13)$. Particularly, regional studies will be more comprehensive and useful in our country, with different cultures and lifestyles in each region. In the present study, the incidence of dental traumas, related factors, and treatment procedures in children admitted to Karadeniz Technical University, Faculty of Dentistry, Department of Pedodontics, from Trabzon and the surrounding cities between 2011 and 2016 were investigated.

\section{Subjects and Methods}

This study was reviewed and approved by the Ethical Committee of Karadeniz Technical University, Faculty of Medicine (2017/227). In total, 416 children aged 1-15 years with a history of dental trauma were admitted to the Karadeniz Technical University, Faculty of Dentistry, Department of Pedodontics from Trabzon and the surrounding cities between January 2011 and 2016. Trauma records were obtained based on the Andreasen and Andreasen classification (14). Standard trauma registry forms were used to obtain all the patients data (age, gender, affected tooth, trauma, time between the trauma and onset of treatment, cause of trauma, type of treatment, and treatment procedure). The cases of multiple trauma types and associated soft tissue injuries were recorded as a combined trauma.

\section{Statistical analyses}

The data collected from all groups were imported to the Statistical Package for Social Sciences (SPSS) for Windows software, version 16.0 (SPSS Inc., Chicago, IL, USA). The type of trauma in the primary and permanent teeth, difference between gender and age groups, and cause of trauma were analyzed using the chi-square test. The distribution of dental traumas by age was calculated using the regression analysis because data distribution did not meet the requirements for normality and homogeneity of variance assumptions. The confidence interval was set to $95 \%$, and a $p$ value of $<0.05$ was considered statistically significant.

\section{Results}

In total, 416 children aged 1-15 years were admitted to our clinic from Trabzon and its surrounding cities because of dental trauma during the 5 year follow-up period (January 2011-January 2016). Table 1 shows the distribution of gender, age, and tooth type of the traumatized children; $37 \%$ of the patients were girls, and $63 \%$ were boys. The mean age was 8.5 years. It was determined that 102 and 314 of these traumas were in the primary and permanent teeth, respectively. Furthermore, dental trauma was more frequently encountered in boys (63\%).

Table 1. The distribution of traumatized children by age, gender and trauma etiology

\begin{tabular}{llcc} 
& & Number (n) & Percentage (\%) \\
\hline \multirow{2}{*}{ Gender } & $\mathrm{G}$ & 154 & 37 \\
\cline { 2 - 4 } & $\mathrm{B}$ & 262 & 63 \\
\hline \multirow{3}{*}{ Age } & $0-3$ & 52 & 12.5 \\
\cline { 2 - 4 } & $4-6$ & 39 & 9.4 \\
\cline { 2 - 4 } & $7-9$ & 137 & 32.9 \\
\cline { 2 - 4 } & $10-12$ & 147 & 35.3 \\
\cline { 2 - 4 } & $13-15$ & 41 & 9.9 \\
\hline \multirow{2}{*}{ Type of tooth } & Primary & 102 & 24.5 \\
\cline { 2 - 4 } & Permanent & 314 & 75.5 \\
\hline
\end{tabular}

The distribution of the causes of traumatic dental injuries by age and gender demonstrated that the most common cause of trauma was falls (61.1\%) in both the girls and boys. This was followed by collisions (11.3\%) and bicycle accidents (8.2\%; Figure 1).

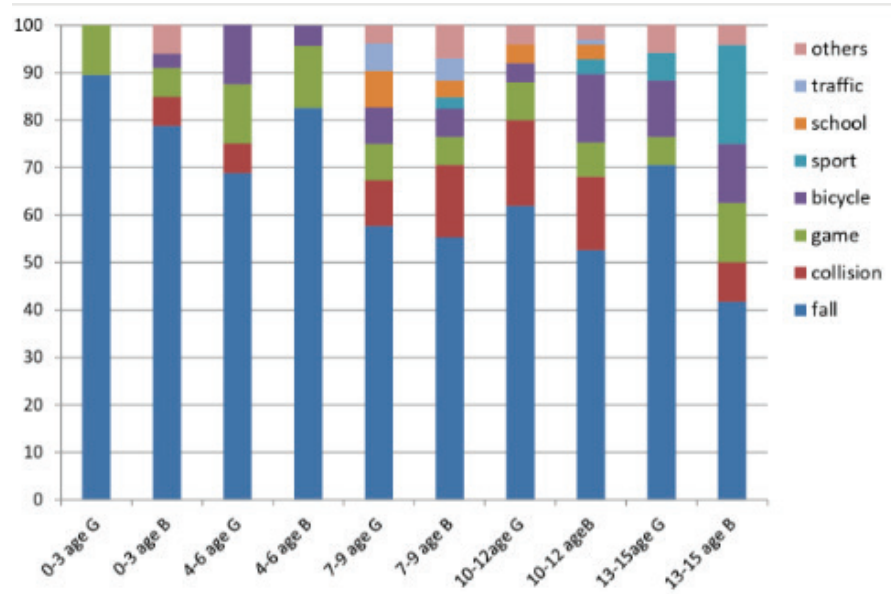

Figure 1. Overall percentage distribution of the causes of traumatic dental injuries by age and gender.

The overall percentage distribution of traumatic dental injuries by age and gender showed that enamel-dentin fracture had the highest ratio (26\%) and it was followed by the combined trauma type with a rate of $21.6 \%$ (Figure 2). 


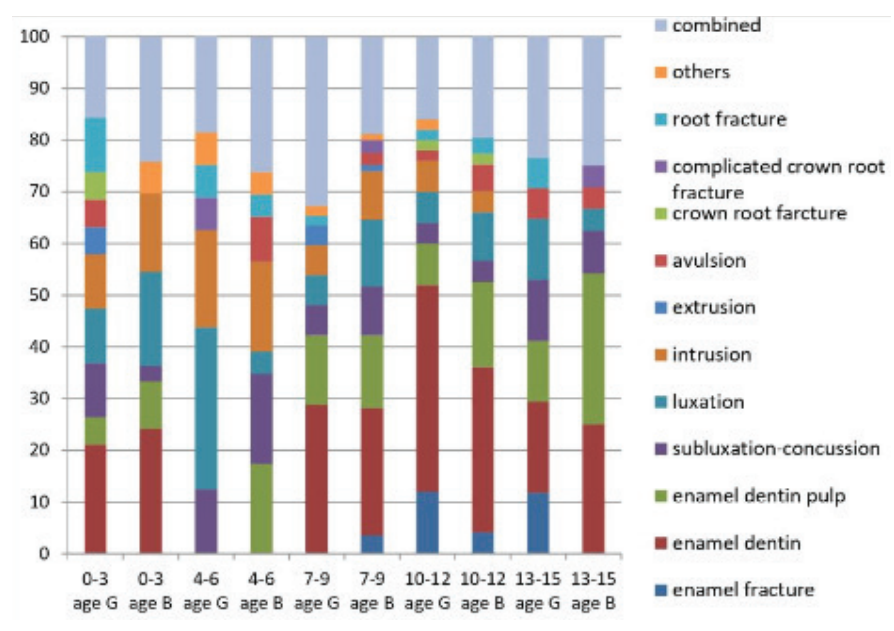

Figure 2. Overall percentage distribution of types of traumatic dental injuries by age and gender.

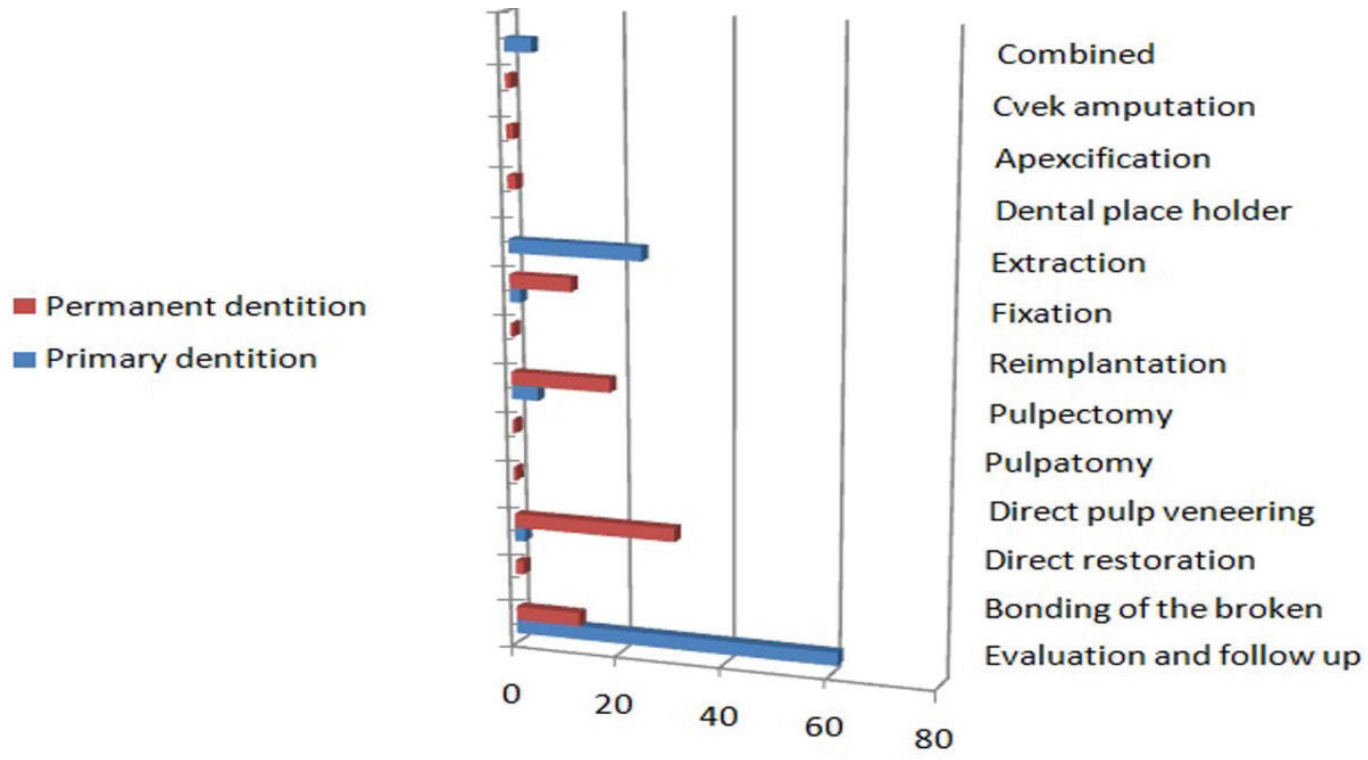

- Primary dentition

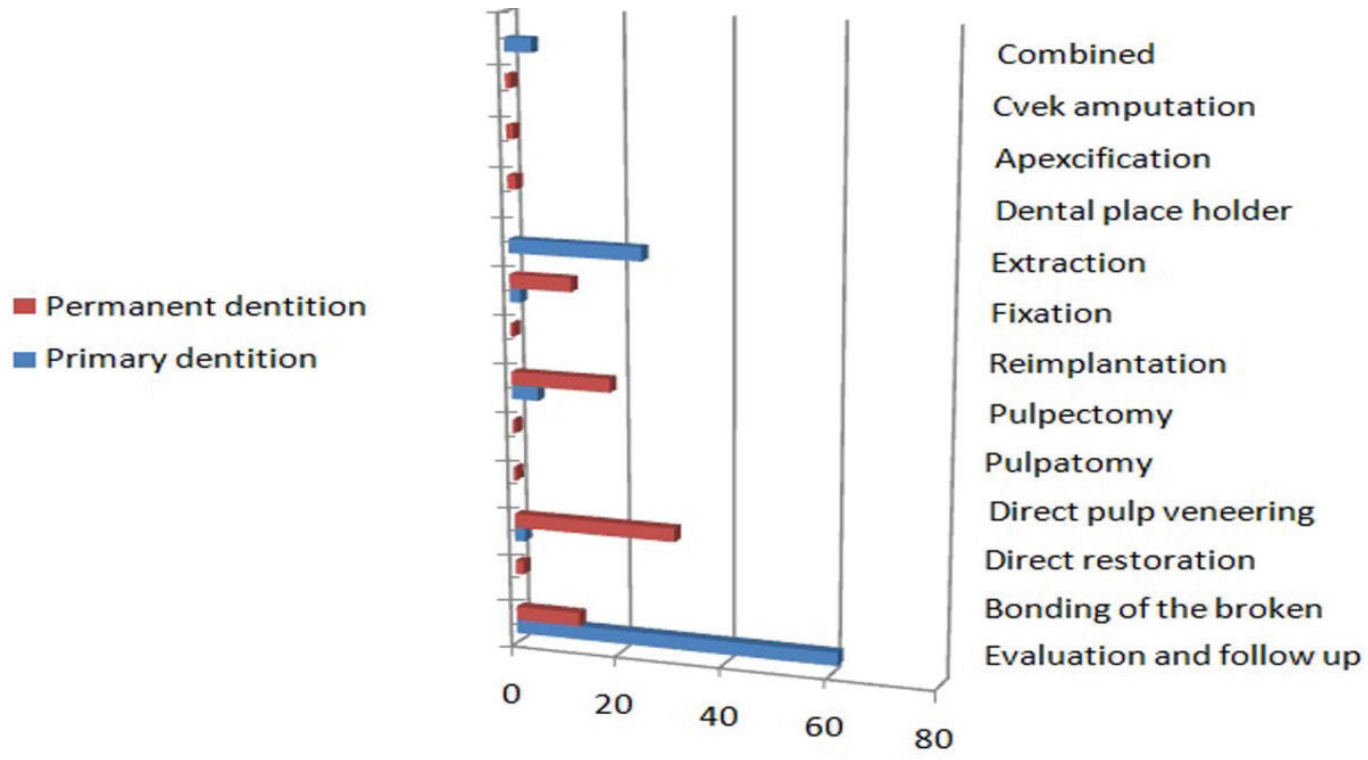

Figure 3. The time interval between the moment of trauma and the onset of treatment.

Figure 4. Distribution of post-traumatic treatment type according to dental type.

When the time interval between the trauma and onset of the treatment was evaluated, the percentage of the patients who initiated treatment on the same day of the trauma was the highest (24.8\%), whereas those who initiated treatment at an unknown time had the lowest percentage (0.5\%) (Figure 3).

Considering the distribution of the treatment procedure for the permanent and primary teeth, follow-up in the primary teeth $(61.4 \%)$ and direct restoration in the permanent teeth
(30.8\%) were determined to have the highest percentages (Figure 4).

The combined trauma and treatment types were separately evaluated, and it was found that the combined trauma type with enamel and enamel-dentin fractures coexisted (1.2\%). The combined treatment type (1.2\%) involving follow-up and direct restoration was more frequent than that involving the other treatment types (Tables 2 and 3 ).

Table 2. Percentage and frequency of the combined types of trauma

\begin{tabular}{lcc} 
Type of Combined Trauma & $\%$ & Frequency \\
\hline Enamel fracture-Enamel Dentin fracture & 1.2 & 5 \\
\hline Enamel Dentin -Enamel Dentin Pulp Fracture & 1.7 & 7 \\
\hline Enamel Dentin Fracture - Subluxation, Concussion & 1.4 & 6 \\
\hline Enamel Dentin Fracture - Luxation Injury & 1.2 & 5 \\
\hline Luxation - Intrusion Injury & 1 & 4 \\
\hline Luxation - Extrusion Injury & 1.4 & 6 \\
\hline Luxation - Avulsion Injury & 1.4 & 6 \\
\hline
\end{tabular}


Table 3. Percentage and frequency of combined treatment types

\begin{tabular}{lcc}
\hline Type of Combined Trauma & $\%$ & Frequency \\
\hline Follow up, Direct Restoration & 1.2 & 5 \\
\hline Direct Restoration, Direct Pulp Veneers & 1.7 & 7 \\
\hline Direct Pulp Veneers, Pulpectomy & 7.5 & 31 \\
\hline Direct Restoration, Cvek Amputation & 0.5 & 2 \\
\hline Pulpectomy, Fixation & 0.7 & 3 \\
\hline
\end{tabular}

\section{Discussion}

Although traumatic dental injuries can occur at any time in our lives, children and adolescents are exposed to these injuries more frequently. Young children are commonly affected by traumatic injuries of the primary teeth. Particularly, in the front teeth, the injuries can adversely affect the development of the underlying dental germ (5). The probability of developmental anomalies in the permanent incisors after a traumatic injury has been reported to be between $12 \%$ and $74 \%$. These anomalies are classified as enamel pigmentation, enamel hypoplasia, crown dilaceration, odontoma-like malformations, root dilaceration, and eruption disorders (9). Andreasen et al. reported that traumatic dental injuries were more frequent during 2-3 years and 9-10 years of age in the primary and permanent tooth dentition, respectively (11).

Children aged 2-3 years need to test their independence as they develop their mobility skills. However, their physical abilities are insufficient to meet these demands; hence, they often have accidents (15). The fact that the incidence of trauma increases at 2-3 years of age can be related to this situation. In the age group of 9-10 years, children are more willing to perform social and sporting activities, and they become aware of their bodies and abilities. Thus, dental traumas may more frequently occur in this age group $(16,17)$. Otuyemi et al. (18) stated that the prevalence of trauma in the primary dentition was higher than that in the permanent dentition. However, in many studies, a dental trauma was reported to more frequently occur in the permanent dentition (19). Also, the prevalence of dental trauma in the permanent teeth was higher than that in the primary teeth in the present study. This is probably because children in the primary dentition period spend more time under parental control; in the transition to permanent dentition, they socialize with the other children during school age, become aware of their bodies and abilities, and increase the sportive activities, which can lead to traumatic injuries $(16,17)$.

In some studies, it has been reported that gender does not have a significant difference in the frequency of dental trauma. However, in many studies, age and gender were found to have an impact on the frequency of dental traumatic injuries $(20,21)$. Epidemiological studies have demonstrated that boys are more likely to have dental injuries than girls in both the primary and permanent dentition periods $(20,22$, 23). In our study, a higher number of dental injuries were found in boys.

Unsafe swings on playgrounds and in wooden blocks in daycare nurseries increase the risk of trauma incidence. As children grow and mature, they become aware of the current risks and can develop reflexes to protect themselves. Injuries in the face and chin area are frequently caused by falls at home or in closed areas at the age of 1-3 years, game and bicycle accidents during school age, and sports or traffic accidents during puberty (24). Dental injuries caused by falls are more frequent in those with mental retardation because of malfunction in motor coordination. In epileptic patients, trauma-related dental injuries were observed in $52 \%$ of the cases (25-27). Frequent dentoalveolar injuries occur because of various traumas, such as fights, falls, traffic accidents, sports injuries, and game accidents (6). The etiology of traumatic dental injuries in our study showed that falls were the most important factor. Gabris et al. (28) and Gassner et al. (29) stated that traumatic injuries generally occur as a result of sports injuries. Avşar (30) reported that dental traumas were more frequently caused by falling off bicycles and falling down the stairs.

Traumatic dental injuries in children were examined according to the type of injury in our study, and enameldentin fractures were determined to be encountered the most. When studies in literature were reviewed, it was found that the frequency of crown fractures varied between $26 \%$ and $90 \%(1,6,12)$. Although many investigators have stated that crown fractures are more common than luxation, Rocha and Cardoso indicated that the frequency of both types of injuries are nearly similar (51.5\% and $48.5 \%$, respectively) and there was no statistically significant difference between them (31). Dental injuries often have a slight impact on the oral soft tissues and teeth and on the periphery depending on the severity of the trauma. However, it is a serious problem that has a negative impact on patients with regard to factors, such as pain, function, aesthetics, and psychology. The severity of trauma on the chin-face area, flexibility, shape and direction of the colliding object, extent to which the lips and other soft tissues reduce strength, strength of the tooth, and chin structure are the main determinants of trauma that can occur in dento alveolar injuries (32). The post-trauma damage to the primary teeth more frequently occurs in the peripheral supporting tissues (periodontal ligament and alveolar bone) than that in the hard tissues of the teeth because of the excessive flexibility of the tissues surrounding the primary teeth and shortness of the primary tooth root. Therefore, it is observed that an adverse impact on the primary teeth usually causes luxation. In the trauma of the primary teeth, the treatment and prognosis of the trauma should be evaluated in terms of the health of the permanent teeth because of their close proximity to the underlying permanent dental germ (3, 21). The injuries of the supporting tissues in the permanent teeth become more frequent around 7-10 years of age when alveolar bone resilience is high, and they become less frequent at the age of $11-13$ years $(2,4,21)$.

Dental trauma is an event that requires elaborating on the application to the dentistry department. An accurate diagnosis, an appropriate treatment plan, and follow-up are important to achieve a positive treatment outcome. The most important factor affecting the prognosis of the traumatized teeth is the time interval between the trauma and onset of the treatment $(12,17)$. A literature review demonstrated that the percentage of patients who consulted a dentist on the same day after trauma ranged $9 \%-48 \%$ (28), whereas it was determined to be $24.8 \%$ in our study. 
The age of trauma is very important for a dentist for two reasons. First, the pulp of the primary teeth, which is wider than that of the permanent teeth, has a better potential for blood circulation and healing. Second, pulp destruction of the immature permanent teeth can cause the roots to become weak and thin or to stop root formation. In this regard, efforts should be made to protect the vitality of the pulp in children with dental trauma $(3,21,33)$. The distribution of the treatment procedure in the permanent and primary teeth revealed that the evaluation and follow-up in the primary teeth and direct restoration in the permanent teeth had the highest percentages in our study. Further, the combined treatment type involving follow-up and direct restoration was the most frequent treatment type.

Dental trauma treatment in children is not only a difficult situation for physicians, but it is also associated with a significant responsibility $(3,12)$. Young children naturally act to discover the environment (3). Research has shown that individuals who spend time with children throughout the day often have no idea of dental injuries. The primary task of families and caregivers is to be prepared for dental traumas. This preparation includes knowing the strategies for protecting from dental traumas and plan of action in an emergency, being aware of the importance of keeping the permanent teeth in milk or saliva, and taking the child to a dentist, and elaborating on this. Dental trauma is a major financial and moral health problem for children and their families. Currently, the most important duty of dentists is to inform and warn child patients, their families, pediatricians, teachers, and sports instructors regarding the issue $(22,30,34)$.

\section{Conclusion}

Our study revealed that boys were exposed to more traumatic injuries, and the most important factor in traumatic injuries is falls. Therefore, teachers, pediatricians, parents, and children should be warned about possible dangers and emergency treatments for all age groups on dental trauma. The percentage of families taking their children to a dentist on the trauma day was found to be very low. It should be explained to the families that it is of great importance to calmly perform an emergency intervention and subsequently visit the nearest dentist at the earliest without losing time for the prognosis of the tooth. Traumatic dental injuries are very common, particularly in school age children. It is necessary to ensure that timely and appropriate treatments are undertaken by informing both families and freelance dentists about traumatic dental injuries.

Türkçe Öz: Karadeniz Teknik Üniversitesi Çocuk Diş Hekimliği Bölümüne Travma Nedeniyle Başvuran Hastaların Değerlendirilmesi: Retrospektif Araştırma. Amaç: Dental travmatik yaralanmalar, süt ve daimi dişlerde sık gözlenen problemler arasında yer almaktadır. Dental travma yaygınlığı dünya genelinde değişkendir. Bu çalışmada, çocuklarda diş travmasının türü, ilişkili faktörler ve tedavi prosedürleri incelenmiştir. Bireyler ve Yöntem: Beş yıllık (Ocak 2011-2016) bir periyotta, Trabzon ve çevre illerden 1-15 yaş arası 416 çocuk hasta, dental travma şikayetiyle kliniğimize başvurdu. Süt ve daimi dişlerde travmanın nedeni, tipi, cinsiyet ve yaş grupları ile ilişkisi ki-kare testi ile yaşlara göre dağılımı ise regresyon analizi ile hesaplandı. Bulgular: Hastaların\% 37'si kız,\% 63'ü erkektir. Yaş ortalaması 8.5 yıl olarak hesaplandı. Travmatik dental yaralanmaların en sık nedeni düşme (\% 61.1) ve en sık görülen dental travma tipi "mine-dentin kırı̆̆ı" idi (\% 26). Sonuç: Çocuklarda dişlerin travmatikyaralanmalarına sıklıkla rastlanılmaktadır. Travmadan sonra hastaların önemli bir bölümünün (\%15.8) herhangi bir klinik semptom oluşmadan tedaviye başvurmadıkları saptanmıştır. Doğru bir teşhis, tedavi planlaması ve olumlu bir tedavi sonucu için öğretmenler, ebeveynler ve çocuklar dental travma gerçekleştiğinde ne yapılması gerektiği ve travma sonrası hemen bir diş hekimine başvurmanın önemi hakkında bilgilendirilmelidir. Anahtar Kelimeler: Diş yaralanmaları; retrospektif çalışmalar; pediatrik diş hekimliği.

Ethics Committee Approval: This study was reviewed and approved by the Ethical Committee of Karadeniz Technical University, Faculty of Medicine (2017/227).

Informed Consent: Informed consent was waived due to the retrospective nature of this study.

Peer-review: Externally peer-reviewed.

Author contributions: $\mathrm{AK}, \mathrm{OFG}, \mathrm{SME}, \mathrm{OB}$ and TT participated in designing the study. AK, OFG, SME, OB and TT participated in generating the data for the study. AK, OFG and SME participated in gathering the data for the study. AK and TT participated in the analysis of the data. AK wrote the majority of the original draft of the paper. AK and OFG participated in writing the paper. All authors approved the final version of this paper.

Conflict of Interest: The authors have no conflicts of interest to declare.

Financial Disclosure: The authors declared that this study has received no financial support.

\section{References}

1. Petersson EE, Andersson L, Sörensen S. Traumatic oral and nonoral injuries. Swed Dent J 1997;21(1-2): 55-68.

2. Andreasen JO, Lauridsen E, Daugaard-Jensen J. Dental traumatology: an orphan in pediatric dentistry? Pediatr Dent 2009;31(2):153-6.

3. Glendor U. Epidemiology of traumaticdentalinjuries a 12 year review of the literature. Dent Traumatol 2008;24(6):603-11. [CrossRef]

4. Andreasen JO, Andreasen FM, Skeie A, Hjørting Hansen E, Schwartz O, Effect of treatment delay up on pulp and periodontal healing of traumatic dental injuries- a review article. Dent Traumatol 2002;18:116-128. [CrossRef]

5. Flores MT. Traumatic injuries in the primary dentition. Dent Traumatol 2002;18: 287-298. [CrossRef]

6. Kramer PF, Zembruski C, Ferreira SH, Feldens CA. Traumatic dental injuries in Brazilian preschool children. Dent Traumatol 2003;19:299-303. [CrossRef]

7. Neto JJ, Gondim JO, de Carvalho FM, Giro EM. Longitudinal clinical and radiographic evaluation of severely intruded permanent incisors in a pediatric population. Dent Traumatol 2009;25:510-514. [CrossRef]

8. Skaare $A B$, Jacobsen I. Dentalinjuries in Norwegiansaged 7-18 years. Dent Traumatol 2003;19:67-71. [CrossRef]

9. Andreasen JO, Bakland LK, Matras RC, Andreasen FM. Traumatic intrusion of permanent teeth. Part 1. An epidemiological study of 216 intruded permanent teeth. Dent Traumatol 2006;22:8389. [CrossRef]

10. Shivayogi MH, Anand LS, Dayanand DS. Management of traumatically intruded permanent incisors. J Indian Soc Pedod Prev Dent 2007;25:13-16.

11. Andreasen JO, Lauridsen E, Andreasen FM. Contradictions in the treatment of traumatic dental injuries and ways to proceed in dental trauma research. Dent Traumatol 2010;26:16-22. [CrossRef]

12. Altay N, Güngör HC. A retrospective study of dento-alveolar injuries of children in Ankara, Turkey. Dent Traumatol 2001;17(5):201-4. [CrossRef] 
13. Kargul B, Cağlar E, Tanboga I. Dental trauma in Turkish children, Istanbul. Dent Traumatol 2003; 19: 72-5. [CrossRef]

14. Glendor U, Marcenes W, Andreasen JO. Classification, etiology and epidemiology. In: Andreasen F, Andreasen JO, Andersson L, eds. Textbook and Color Atlas of Traumatic Injuries to the Teeth. 4th ed. Oxford: Blackwell; 2007. p.217-54.

15. Pinkham JR. [Change of the the dynamics]. In: Pinkham JR, Casamassimo P, McTigu DJ, Fields HW, Nowak AJ, eds. Tortop T, Tulunoğlu Ö, çeviri editörleri. Çocuk Diş Hekimliği Bebeklikten Ergenliğe. 4. Baskı. Ankara: Atlas Kitapçılık; 2009. p.166-205.

16. Kizilci E, Demir P. [Evaluation of epidemiology and etiology of dental injuries observed in children]. Med-Science 2015. doi:10.5455/medscience.2015.04.8260. [CrossRef]

17. Rocha MJ, Cardoso M. Traumatized permanent teeth in Brazilian children assisted at the Federal University of Santa Catarina, Brazil. Dent Traumatol 2001;17(6):245-9. [CrossRef]

18. Otuyemi OD, Segun-Ojo Ol, Adegboye AA. Traumatic anterior dental injuries in Nigerian preschool children. East Afr Med J 1996;73(9):604-6.

19. Forsberg $C M$, Tedestam G. Etiological and predisposing factors related to traumatic injuries to permanent teeth. Swed Dent J 1993;17(5):183-90.

20. Bastone EB, Freer TJ, McNamara JR. Epidemiology of dentaltrauma: a review of the literature. Aust Dent J 2000;45:29. [CrossRef]

21. Kuşcu ÖÖ, Sandallı N, Çağlar E. [Dental trauma in children]. Yeditepe Diş Hekimliği Dergisi 2011;3(2):6-14.

22. ZuhalK, Semra OE, Hüseyin K. Traumatic injuries of the permanent incisors in children in southern Turkey: a retrospective study. Dent Traumatol 2005;21(1):20-5. [CrossRef]

23. Saroğlu I, Sönmez H.The prevalence of traumatic injuries treated in the pedodontic clinic of Ankara University, Turkey, during 18 months. Dent Traumatol 2002;18(6):299-303. [CrossRef]
24. Forsberg CM, Tedestam G. Etiological and predispozing factors related to traumatic injuries to permanent teeth. Swed. Dent. J. 1993;17:183-90.

25. Sivakumar N, Muthu MS. Traumatic injuries of teeth and supporting structures. In: Sivakumar N. Muthu MS, eds, Pediatric Dentistry Principles and Practice. Delhi: Elsevier, 2012;305.

26. Turkistani J, Hanno A. Recent trends in the management of dentoalveolar traumatic injuries to primary and young permanent teeth. Dent Traumatol. 2011;27(1):46-54. [CrossRef]

27. Andreasen JO. Etiology and pathogenesis of traumatic dental injuries A clinical study of 1,298 cases. Scand J Dent Res. 1970;78(4):329-42. [CrossRef]

28. Gabris K, Tarjan 1, Rozsa N. Dental trauma in children presenting for treatment at the Department of Dentisty for Children and Orthodontics, Budapest. Dent. Traumatol 17:103-108;2001. [CrossRef]

29. Gassne R, Bosch R, Tuh T, Eınshoff R. Prevalence of dental trauma in 6000 patients with facial injuries. Oral Surg. Oral Med. Oral Pathol. Oral Radiol. Endod, 87: 27-33, 1999. [CrossRef]

30. Avşar A. 7-14 Yaş Grubu Çocuklarda Görülen Travmatik Yaralanmaların İncelenmesi. Cumhuriyet Üni. Diş Hek.Fak. Dergisi.2002; 5(2).

31. Rocha MJC, Cardoso M. Traumatized permanent teeth in Brazilian children assisted at the Federal University of Santa Catarina, Brazil. Dent Traumatol. 2001;17(6):245-9. [CrossRef]

32. Özel $E$, Altundal $H$, Dentoalveolar ve perioral yumuşak doku yaralanmaları, 2006, Atatürk Üniv. Diş Hek Fak Derg, 4, 7-13.

33. Caglar E, Kuvvetli SS, Sandalli N. Safety for children of play equipment and surfaces in playgrounds regarding dental trauma. JOHDMBSC. 2010; 9:63-8.

34. KızılCı E, Demir P. Evaluation of Epidemiology and Etiology of Dental Injuries Observed in Children [Çocuklarda Görülen Diş Yaralanmalarının Etiyoloji ve Epidemiyolojilerinin Değerlendirilmesi]. Medicine Science. 2015; 4(3). [CrossRef] 